\title{
The Uncanny Robots of Pilot Pirx: Stanisław Lem's Tales
}

\author{
DOMINIKA ORAMUS
}

\begin{abstract}
There was a time when Stanisław Lem was the best sold and read writer in Poland (though he was even bigger in the Soviet Union and East Germany). His popularity steadily grew from the time of his debut and reached its apogee in the late nineteen-sixties. For literary critics the death of Lem ten years ago, in 2006, is a closure of his rich and diverse oeuvre, and this has opened new perspectives on 'lemology', which at the Polish language departments of some universities is a minor branch of literary studies. Indeed, in different decades of the $20^{\text {th }}$ century Polish academia discussed Lem from a range of vantage points. In his lifetime Lem provoked conflicts and antagonisms. The aim of this paper is to discuss the presentation of a motif Lem often comes back to, namely the motif of the robot, in four of his short stories from the Pilot Pirx cycle. I shall do so in such a way as to show how different critical traditions contribute to my full understanding of the text. The stories I have chosen are "Terminus", "The Hunt", "The Accident" and "The Inquest". I will also allude to "The Mask". First I need to briefly describe how 'lemology' evolved in Poland and how it was prompted by Western criticism. Thereafter I will present the stories I have chosen. Finally, I am going to portray the development of the robot motif in the Pirx cycle in reference to both Polish and foreign critics.
\end{abstract}

Keywords: Stanisław Lem; human simulacra; the uncanny; humanness

\section{The impact of Lem's work and his heritage}

The death of Stanisław Lem in 2006 is a significant date for Polish Science Fiction, as in his lifetime SF developed significantly. The pre-war quasi-Gothic tradition was transformed and, after the years of political censorship and the ideological straight-jacket of socialist realism, Polish SF maturated into rich allusive writing. Some thirty years ago new literary fashions appeared in the country. This included both political fiction set in the near future and fantasy literature, which became popular. Moreover, thanks to the new economic situation, 'private' publishers introduced the world's SF classics to Polish readers. Still, the gigantic figure of Lem was to be felt everywhere: all the younger SF authors tried to write 'in the way Lem does' or 'against the way Lem does'. Only towards the end of his life, once Lem had decided not to write 
fiction any more, did the youngest generations of cyberpunk and fantasy fans neglect his silent presence and pretended Lem was not there. Although Lem's death was considered a very important event at Polish universities (session and panel discussions were organized, in memoriam volumes of criticism were being prepared) the reaction of young Polish fandom outside academia was lukewarm or none. During the Nidzica Convention (June 2006) not a single event was dedicated to Lem. The major SF magazine "Nowa Fantastyka" devoted to Lem a short obituary in the middle of the issue, not considering his death important enough to be signaled on the cover. Moreover, it is worth mentioning that Lem was never given the Zajdel Award (Poland's annual SF fans award for the best SF novel and short story), which was probably due to his pronounced contempt for modern SF, new literary fashions, and contemporary young people in general.

For Polish critics the death of Lem is also a closure of his rich and diverse oeuvre, and this has opened new perspectives on 'lemology', which at the Polish language departments of some universities is a minor branch of literary studies. Indeed, in different decades of the $20^{\text {th }}$ century Polish academia discussed Lem from a range of vantage points. In his lifetime Lem provoked conflicts and antagonisms. His undisputable literary genius and enormous sales made him 'choosy' as far as agents, editors and critics went (Lem decided who would write about his books etc.) From the late 1950s to the early 1990s Lem sold well in Poland (the number of copies in the market was first limited by the country's editorial policy and technical problems: availability of paper etc.), but in the Soviet Union millions of copies were 'absorbed' by the hungry market. There Lem was one of the most lionized foreign authors and his visits to Moscow in the 1960s and 70s provoked outbursts of hysteria among fans. Furthermore, his critical opinions were often offensive. ${ }^{1} \mathrm{His}$ literary output has always been 'in between' SF and the mainstream, literature and philosophy, popular science and futurology - and none of the critical approaches could encompass such diversity. Lem has always been unsatisfied with the reception of his prose and seems to have been dissatisfied with the late $20^{\text {th }}$ century world at large: SF, literature, civilization. In Tako Rzecze Lem (Thus Spake Lem) Lem, interviewed by Stanisław Bereś, describes his attempts to improve the quality of SF in the world. He contributed to Quarber Merkur

See Science Fiction Studies, 12, vol. 4, part 2, July 1977 where the "Lem Affair" is described. Pamela Sargent and George Zebrowski present the events leading to Lem'sbeing ousted from the SFWA, which was mostly due to his severe criticism of other people's books. Similarly unpleasant conflicts terminated Lem's friendship with Franz Rottensteiner and many Polish critics and writers. 
a German-language magazine edited by Rottensteiner with a "Let's fight literary rubbish" slogan on each cover, writing very angry articles about the deterioration of artistic standards in the Western SF. He spent his last years in Kraków living quietly, from time to time appearing at some session devoted to his writing or giving interviews. ${ }^{2}$

\section{Evolution of 'lemology' in Poland}

The aim of this paper is to discuss the presentation of a motif Lem often comes back to, namely the motif of the robot, in some of his short stories from the Pilot Pirx ${ }^{3}$ cycle. I shall do so in such a way as to show how different critical traditions contribute to my understanding of the text. The stories I have chosen are "Terminus", "Polowanie” (The Hunt), "Wypadek" (The Accident) and "Rozprawa" (The Inquest). I will also allude to "Maska" (The Mask). ${ }^{4}$

First I need to briefly describe how 'lemology' evolved in Poland and how it was prompted by Western criticism. Thereafter I will present the stories I have chosen. Finally, I am going to portray the development of the robot motif in the Pirx cycle in reference to both Polish and foreign critics.

There was a time when Lem was the best sold and read writer in Poland (though he was even bigger in the Soviet Union and East Germany). His popularity steadily grew from the time of his debut and reached its apogee in the late nineteen-sixties. Nonetheless, for quite a while there was no critical assessment of his work - only some reviews. In the Stalinist era Lem had problems with publishing his early non-SF novel Szpital Przemienienia ('The Transubstantiation Hospital'). He started writing this book (set in a psychiatric hospital under the German occupation) in 1948. As the novel was

2 In his criticism Lem did not spare the way scholars approach his oeuvre. The "super savants of Science Fiction Studies" (Bereś 2002: 546) who read his novels referring to theories of Lacan and Derrida seemed to him clumsy and unclear. In Polish the word 'savant' has two gender-specific forms (as in French), Lem uses the feminine form "super-sawantki", which gives his remark an antifeminist tinge.

3 "The Accident", "The Hunt" and “The Inquest” in: More Tales of Pirx the Pilot, tr. Louis Iridarne with the assistance of Magdalena Majcherczyk and Michael Kandel, Harcourt Brace and Company, San Diego, New York and London 1983; "Terminus” in: Opowieści o Pilocie Pirxie, "The Collected Works of Stanisław Lem", Wydawnictwo Literackie, Kraków, 2002.

4 “The Mask" in: Fantastyczny Lem, Wydawnictwo Literackie, Kraków, 2003. This story is very popular with Western critics, see for example Parker 1992. The careful analysis of this rich and difficult story is far beyond the scope of my paper, but as this text is both narrated and focalized by the robot I need to refer to it from time to time. 
unacceptable to the communist authorities, Lem had to "add" to it two heavily ideological volumes picturing lives of the protagonists after the war in a happy communist wonderland. The whole trilogy which Lem hated was published in 1955. The original one-volume edition was not published until 1975. After this experience Lem refrained from writing realist fiction and as a result he turned to science fiction, which at the time was neglected by the critics. Not knowing how to assess 'unserious' writing, the reviewers of his early texts chose to write about his grotesque texts Cyberiada, Dzienniki gwiezdne (The Cyberiad, The Star Diaries) from the point of view of linguistics (neologisms, linguistic humor etc.). Only the 'serious' quasi-philosophical books such as Summa Technologiae were considered worthwhile.

In the 1970s the first book-length assessments of Lem's fiction were published. This coincided with the publication of the first critical papers devoted to the theory of science fiction. ${ }^{5}$ Powieści fantastyczno-naukowe Stanistawa Lema ('The SF Novels of Stanistaw Lem') by Andrzej Stoff is worth mentioning. Published in 1983 (though written earlier) it is one of the first book-length papers about Lem. According to Stoff, Lem's poetics is based on transgressing the borders of literary genres. Similar approach is taken by Piotr Krywak who in Fantastyka Lema: Droga do "Fiaska" ('Lem's Science Fiction: A Road to "Fiasco"') shows that much of Lem's SF is in fact written according to detective fiction conventions with the protagonist gradually discovering some enigmas. Krywak also interprets the ideological and philosophical evolution of Lem: from initial fascinations with anthropocentrism and rationalism through the growing skepticism to the final pessimism and, in Pokój na Ziemi ('Peace on Earth'), even catastrophism. Since that time a lot of scholars have been interested in Lem and Lem-loving professors (Antoni Smuszkiewicz in Poznań, Andrzej Stoff in Toruń, Jerzy Jarzębski in Kraków) have supervised a number of MA and PhD theses analyzing his oeuvre. Finally, Lem has acquired the status of a classic and it is within academia that he is nowadays read. Jerzy Jarzębski edited the prestigious Dzieła zebrane Stanisława Lema ('The Collected Works of Stanistaw Lem') series in Wydawnictwo Literackie, writing afterwords to each of the volumes. Antoni Smuszkiewicz wrote Stanistaw Lem, a popular textbook addressed to students - as since the late 1980s Lem's texts are in primary and high school syllabuses.

In the early 1980s, during Martial Law in Poland, Lem gave a number of lengthy interviews to Stanisław Bereś, where he described his life, books,

One should mention here Fantastyka, Utopia, Science Fiction, The Fantastic (Utopia and Science Fiction) by Andrzej Zgorzelski and works by Andrzej Niewiadomski and Antoni Smuszkiewicz. 
ideas and predictions for the future of the world. Because of censorship the book that thus arose was first published in German. ${ }^{6}$ A censored version was published in Poland in 1987. Only in 2002 was the full text (with some new chapters added) published in Poland, under the title Tako Rzecze Lem ('Thus Spake Lem'). This 550-page long interview is now the standard account of Lem's ideas and personality, though other interviews are also available. ${ }^{7}$

Though all his life he tried to be nationally-neutral, Lem writes from a very special point in time and space: the crossroads of European history, a place in between cultures. The very place he was born, Lwów, was once a Polish educational and scientific centre during the Habsburg monarchy. Just before Lem was born it had become one of the major cities in Free Poland. Then, when Lem was hardly of age, it was occupied by the Soviets, then taken by the Germans, then finally taken back by the Soviets who occupied it for the most of Lem's lifetime. Lem in his early twenties emigrated to Kraków and lived there till the proclamation of Martial Law in Poland in 1981. He then left for Austria and came back to Kraków only after communism had ended. Soon after this the Soviets left Lwów and, with the Polish intelligentsia dead or emigrated, the city became Ukrainian and Lem decided never to visit it again. Thus the last time he saw his family home was in 1945 . The epochs he knew were the past of diverse national cultures and the today of emerging global culture.

\section{Reception of Lem's work by Western critics}

Polish scholars have always been interested in the way Lem is received abroad, and thus new papers are written with the awareness of Western criticism. Thus Lem w oczach krytyki światowej ('Lem In the Eyes of the World Critics'), edited by Jerzy Jarzębski, a volume of papers by Western critics was published and sold in Poland, and numerous conferences with the participation of foreign (mostly German) scholars have been organized in the recent years. Moreover, when in the last years of the communist regime the Polish translation of James Gunn's anthology The Road to Science Fiction appeared on the market, featuring Lem as the only Polish writer, SF fans got to know about 'the overseas" perspective in reading Lem. Non-academic readers have discussed the gossip about Lem's troubled friendship with Philip K. Dick; they felt proud that Kurt Vonnegut, Michael Kandel and Alvin Toffler appreciated his prose; and disliked the Western reviewers who underestimated Lem's cultural background. Jerzy Jarzębski in his Introduction to Lem In the Eyes of the World Critics quotes

6 Lem uber Lem. Gesprache, Intel-Suhrkamp Verlag, 1986.

7 See Fialkowski 2001. 
for example Anthony Burgess' review of Lem's Próżnia doskonała ('A Perfect Vacuum'), where Burgess asks straightforwardly if it is possible for an intellectual like Lem to live in "primitive Poland" (6).The motif of robots (or in a broader perspective, living dolls and statues) places Lem's fiction within the well-established European tradition and allows for diverse readings of his Pilot Pirx tales.

Since Ovid's Metamorphoses and the Pygmalion and Galatea story, the relationship of genuine humans and human simulacra has recurred in European writing in nearly every epoch: Shakespeare's The Winter's Tale and Molière's Don Juan bring about the living statue motif and introduce it within the context of the uncanny - later Gothic and horror texts very often use this connotation. In the $18^{\text {th }}$ century La Mettrie and de Sade describe mechanical human beings (man-machine and les maitresse-machines) using an automaton as a pretext to discuss philosophical questions concerning the definition of man and humanity.

Later, De Villiers de l'Isle-Adam and Mary Shelley show artificial human beings as sources of fear and amazement: romanticism re-establishes the horrifying quality of human simulacra. E. T. A. Hoffman's "The Sandman” is the best known example of a living-doll horror text. In his famous essay "The Uncanny” Sigmund Freud analyzes Hoffman's story showing that what we instinctively fear and consider uncanny and dangerous are instances of the violation of the living/dead dichotomy. He defines 'uncanny' (in German 'unheimlich') in the following way:

What interests us most in this long extract is to find that among its different shades of meaning the word 'heimlich' exhibits one which is identical with its opposite, 'unheimlich'. What is heimlich thus comes to be unheimlich. (Cf. the quotation from Gutzkow: 'We call it unheimlich"; you call it "heimlich".') In general we are reminded that the word 'heimlich' is not unambiguous, but belongs to two sets of ideas, which, without being contradictory, are yet very different: on the one hand it means what is familiar and agreeable, and on the other. what is concealed and kept out of sight. (Freud 1973:4)

Automatons and living dolls, which are neither dead nor alive, blur this distinction and thus provoke the feeling of inexplicable horror. In the $20^{\text {th }}$ century this was the subject of innumerable stories and films about uncanny beings. ${ }^{8}$ In 1921 the word 'robot' appeared for the first time in Karel Čapek's

8 Among them the early $20^{\text {th }}$ century horror stories by Stefan Grabinsky, which Lem refers to in Thus Spake Lem, calling them one of the texts he had in mind writing his early SF, especially “Terminus” (Bereś 2002: 82). 
novel R.U.R. and soon it was assimilated into many European languages, among them Polish. Lem comments on the term 'robot' and its global success in his Fantastyka ifuturologia. (Lem 2003a: 357)

\section{Presentation of the stories under consideration}

What Lem does in his Pirx tales is to come back to this cultural tradition, albeit in a quite unexpected manner, namely, in the totally rationalist Universe focalized by Pirx, who is himself an embodiment of common sense and logic. Pirx seems to be the best loved of Lem's protagonists and the only one who is decent, modest and honest, and who, though no one knows it, always wins. It is he who resolves all enigmas, manages to handle the most difficult situations, though somehow this all goes unnoticed:

The consecutive tests the hero undergoes all end well, and, most important, the author stresses that in every case Pirx was successful where specialists, or whole teams of them, had previously failed. Is he then just another of the "cosmic heroes" with which trivial SF abounds? Lem is not that naïve, Pirx does not beat the experts with their own weapons, all of his successes are based on chance... Pirx is not a systematic thinker, but he is possessed of an extraordinary intuition. (Jarzębski 1977: 120)

It is this "intuition" which most of the critics elaborate upon; itself a heritage of the pre-sapiens era, intuition derives from our animal ancestry, the biological side of our personality. In moments when logic and rationality fail, the imperfect 'instinctive' reactions save the day. It is Pirx's short-comings, his emotionality and defensiveness that prove advantageous and enable him to win when perfect machines and proud, machine-like specialists fail. In "Pirx i sekrety człowieczeństwa" ('Pirx and the Secrets of Humanness') Jarzębski discusses the tales as Bildungsroman: in the first Pirx is a young cadet, in the last a commander. Moreover, in parallel to the maturation of the protagonist, the difficulty of the problems he has to deal with grows - right along with his physical prowess, practical skills, cleverness and intellectual abilities. In a sense Pirx is an Everyman in the times of advanced technology and "the mystery of strange beings, events and localities [educate Pirx] into understanding the limitations and strengths of humanity." (Suvin 1993: 711)

As such a representative of the human race Pirx often encounters robots: on the one hand his humanness is defined in contrast to artificial intelligence, but on the other the robots turn out to be 'tainted' with humanity, as their 
creators unwillingly made them in their own image. In the above mentioned essay, Jarzębski proves that the contamination with humanness finally destroys the robots: Aniel ("The Accident") crashes down when he tries to climb a mountain to prove himself an alpinist, the Setaur ("The Hunt") is killed because he hesitates for a moment seeing in Pirx his ally, Calder ("The Inquest") has the inhuman, perfect intellect but also a human's imperfect pride and contempt. Even Terminus is sentenced to be re-cycled because of human neurosis over his mechanical brain. In "The Hunt” Pirx and other astronauts, who happen to be staying at a lunar hotel, have to hunt down the Setaur, a mining robot. For after a meteor hit the storehouse the Setaur's brain was partly destroyed, though his mechanical abilities remained intact. The remaining part of the robot's nervous system then takes over, making the Setaur aggressive towards all movement - he suffers a kind of robotal paranoia. In "The Accident" Pirx encounters a yet more elaborate "nonlinear" robot, Aniel, who is so complicated that he develops a proto-personality. One day during a scientific expedition on an empty planet he goes to the mountains to collect some data and disappears. Finally the rescue team discovers his smashed body and only Pirx intuitively knows that Aniel had tried to climb a difficult wall just to test himself.

In "The Inquest" Pirx is hired by a space corporation to test a new kind of crew, some of whose members are not people but androids (again, as in the case of Aniel, Lem refrains from using the word "android", he calls the robots "nonlinears"). Pirx's task is, without knowing who is who, to assess the abilities of all his men and thus to qualify or disqualify androids as astronauts. Calder, the robot hidden among the men, contrives an accident which would kill all the humans but allow the robots to save the ship, thereby proving themselves indispensable in space. However, in the most dire moment of the crisis, Pirx, instead of giving him orders (which was the most important item in Calder's intrigue), is silent, not knowing what to say. Calder has to improvise, which he is poor at, and starts committing mistakes until he gets destroyed and the human pilots fly home.

These three robots represent growing neural complexity and technical ingenuity - and this requires more and more attention and reverence on the part of humans. In order to present the full spectrum of possibilities, let us also mention two other examples: the most advanced robot Lem ever described: an ingenious executioner machine from "The Mask" and the title character of "Terminus": a primitive robot of scarce mental abilities.

"The Mask" is both narrated and focalized by a killer-robot in the form of a beautiful lady who gradually discovers her true identity and, summoning all her will, tries to subvert her pre-programming and not to kill the man 
she was made to destroy. "Terminus", one of the pilot Pirx tales, shows Pirx at the beginning of his space career. Young and still inexperienced he has to transport some merchandise to human colonies on Mars, but the ship he gets from his bosses is very old and dangerous to pilot, especially in that its nuclear engine is leaking.

Just as in Freud's "The Uncanny", this tale of a quasi-human Terminus is told in a mis-en-scene of horror with supernatural innuendoes. A gigantic, empty ship, rusty machinery, a murky past and dusty pilot seats set the mood at the very beginning. In fact, many years previously the ship had been a famous transporter: but after a space catastrophe, it became a veritable coffin for the crew who survived, drifting in space in separate half-crashed cabins till their oxygen ran out. When the ship was finally recovered the only "survivor" was Terminus, a primitive automaton whose job was to fix leakages (his simple brain cannot control anything more). Terminus seems to be able to do his job, but by some freak phenomenon the rhythm of his iron hands patching the leaks repeats the sequences of the Morse signals the dying crew had hammered on the pipes to communicate with one another. Pirx tries not to give up to the uncanny and in a rational manner sets about to explain what is wrong with Terminus who, though mentally uncomplicated, seems to suffer from the posttraumatic stress disorder.

In all these robot stories variations and improvisations on the same set of subjects recur. The repetitive elements present in all or most of the tales might be categorized and labelled: personification of automatons; adaptability of their brains; and the madness they suffer and provoke.

\section{The development of the robot motif in the Pirx cycle}

Personification. In all the Pirx cycle stories we see the world exclusively via his eyes. Pirx is the focalizer. The third person narrator gives his own views and opinions very rarely, for instance in the initial stories he sometimes tells the reader something about Pirx he himself does not know (his looks, what his professors think about him, etc). But mostly we see what Pirx sees and pass judgments according to his value system. Pirx's thoughts are quoted or paraphrased in free indirect speech, which allows the narrator to refrain from giving his own views. Therefore we do not see automatons 'objectively', but in the way Pirx does. Subjectively, Pirx personifies them and, in critical situations, he has the ability to "feel like the machine", owing to which he solves problems the professors of cybernetics cannot. 
ORAMUS

Such a focalization makes the descriptions of robots sound very humanlike. In "Terminus" we learn that the automaton was "senile", "clumsy" and ashamed of his disability. There is no way of saying to what extent this is just Pirx's own, perhaps wrong, impression. In "The Hunt” Pirx is the only one to look for logic in the Setaur's seemingly absurd actions: "What would he do, after all, if he were the Setaur? Immediately he felt alarmed, for he was certain that he - in his place - would attack" (Lem 1983: 80). ${ }^{9}$ What is more, only by personifying the robot and adapting his point of view can Pirx guess what really happened in the final scene of the Setaur's rebellion. How did people manage to destroy the invincible robot? "In that hesitation, that uncertainty, which Pirx could understand full well, there was something so uncannily familiar, so human, that he felt a lump in his throat. What would I do in his place, what would I think? (Lem 1983: 83). ${ }^{10}$ The Setaur's madness is human and Pirx feels ashamed to have killed somebody so handicapped.

In "The Accident” Pirx prefers Aniel to the quarrelsome human colleagues with whom he has to spend his days during the long stay on a distant planet. He takes the side of the robot consciously: one night, while falling asleep he imagines how stressful it must be for robots to have to put up with their masters, and he day-dreams of a robot revolt in which he would help the underprivileged machines in their fight against people. During his waking hours he is ashamed of such childishness, but he still believes that the best way of judging man's morals is to watch how he treats or mistreats robots. The very fact that people created slave-like intelligent beings (and equipped them with blockades maiming their spiritual development) is for him unfair: "a very clever but none the less nasty trick" (Lem 1983: 25). ${ }^{11}$

In "Inquest" "the finite nonlinears" are apparently shown to be hostile and detached, but Pirx is aware that they were designed to be like that and that only people are to blame for having constructed something so dangerous. $\mathrm{He}$ tries to 'tune-in' to the nonlinear psyche and predict their moves, although at the same time he feels dishonest and is disgusted by the fact that people have forced robots to mimetically reproduce their own form - a result of biological evolution. "What a mean, coldhearted, soulless... But is it really his fault? More like a classic sorcerer's apprentice" (Lem 1983: 152) ${ }^{12}$ Pirx ponders upon nonlinear nature. On the one hand, nonlinears designed to pilot passenger

9 Tr. Louis Iridarne with the assistance of Magdalena Majcherczyk and Michael Kandel. In the original Pirx's thoughts are quoted, not related in the third person.

10 Tr. Louis Iridarne with the assistance of Magdalena Majcherczyk and Michael Kandel.

11 Tr. Louis Iridarne with the assistance of Magdalena Majcherczyk and Michael Kandel.

12 Tr. Louis Iridarne with the assistance of Magdalena Majcherczyk and Michael Kandel. 
starships must look like us to be acceptable to spaceways clients. On the other, people are unprepared to co-exist with human simulacra and fear the living dolls. Again the association is with Freud's "The Uncanny", the essay where the anxiety that living dolls provoke is associated with the return of the repressed unconscious material to the conscious psyche and the animistic mode of thinking dating from the dawn of human development. The blurred division between animate and inanimate, real and imaginary seems uncanny because it stirs early memories of a stage of individual development (and simultaneously an early stage of human culture) at which these distinctions were not yet made. Therefore we should not be surprised that nonlinears inherited the worst characteristics of their masters and they are justified to blame us for their grotesque existence: " $[\mathrm{h}] \mathrm{e}$ is lying to himself if he doesn't think he hates his creators. I sure would" (Lem 1983: 142) ${ }^{13}$, Pirx says to himself again trying to identify with the robot.

The pilot is persistent in evaluating robots with a human measure, even against the opinion of "master engineers" who tell him he is wrong. Pirx's technique works and therefore he proves that robots do have some pre-human personality. In "The Mask" we deal with the opposite situation, a narratormachine looks at people and, interestingly, she notices mostly robot-like, mechanical traits. At the court ball she feels she is among "dancing manikins" (Lem 2003: 316) ${ }^{14}$ and the butler's face looks to her like "a mask so servile that it was like a doll's face: a living, wax corpse” (Lem 2003: 318) ${ }^{15}$.

Discovering her true identity as a pre-programmed artifact involves a lengthy process of probing her own inside to find some imprinted limitations: things she was forbidden to do and say. Her self-analyzing and intellectual struggle with the program-destiny makes the Mask seem very human, the reader automatically personifies her (when we read about her we think about a woman, not about an iron executioner). In "The Mask" the protagonist is more than a simple android. At the beginning of the narrative she is an artificial beautiful girl equipped with what she needs to pass for an aristocrat at the King's court. Then, in an act of pre-programmed self-mutilation she cuts her girl's body open and finds inside an iron chrysalis - an executioner-machine which behaves like a clockwork animal. The narrator is nevertheless still herself, in the intellectual meaning of the term, all the time her intelligence and sexual identity are intact, though physically she changes from a quasihuman being to a quasi-animal. Such an exposition of the arbitrariness of

13 Tr. Louis Iridarne with the assistance of Magdalena Majcherczyk and Michael Kandel.

14 Tr. mine, D.O.

15 Tr. mine, D.O. 
the shape the brain "wears" is hard to grasp for human readers. The Mask possesses free will, which is for her a tool for overcoming the iron parasite inside - precisely as is the case with human beings struggling with their instincts and impulses. The tension between the mechanical and the human side of the protagonist's ego makes Lem's heroine similar to the protagonists of Philip K. Dick's. In We Can Build You the narrator obsessively fears that he had been replaced by an ingenuously programmed homunculus, while one of the other characters quotes Spinoza saying that man is just a biological machine. Rick, the protagonist of Do Androids Dream of Electric Sheep? also ponders the possibility that an android with an artificial memory implant might be subjectively sure she or he is human.

The protagonist of "The Mask" is herself a victim of her constructors' manipulation: equipped with multiple memory, she thinks she remembers three separate pasts of three different human girls and each of these seems to be herself. The incoherence of self-contradicting memories makes the Mask rule them out as false and to realize she has no past, only the superior logical executioner-program which knows no feelings.

Adaptability. In order to deal with complicated and unpredictable situations, artificial brains need adaptability. Therefore robots usually have intellectual powers beyond a necessary minimum. The association with the human brain and its ability of lateralization are inescapable. Thus, in the case of androids (just as in the case of humans) the same psychic functions can be exercised by different parts of the brain. The partly damaged brain can thus still function, though probably not in the way its designers had wished.

In "The Hunt" the party following the Setaur curse the neural redundancy which makes him so difficult to outwit (even worse, his physical prowess and sheer energy are far superior to man's). The nonlinears are "better" also in "The Inquest"; their physical endurance and intellectual superiority make them very proud. The anonymous letter Calder sends to Pirx is full of contempt for the human race with its biological heritage of irrationality. None the less, the second nonlinear in the crew, Burns, is aware that robots lack intuition and thus are handicapped in a mysterious but important way. Thanks to his humility and modesty he helps Pirx defeat Calder. The moral is that the nonlinears differ from one another, just like people do, and this probably results from the complexity their brains.

Madness. For some reasons (I would venture the influence of Freud) numerous narratives describing androids and living dolls have a subplot dealing with madness: either the robots or their masters are insane. This connotation (robots, therefore madness) is parodied by Douglas Adams in his The Hitchhiker's Guide to the Galaxy in the character of the paranoid android 
Marvin. A propos Adams it is worth mentioning that one of the SF standard motifs he applies to his novel is derived from Lem's The Cyberiad. In Adams's story the starship the Heart of Gold is equipped with an improbability drive, the application of which results in a spontaneous occurrence of most improbable co-incidents. A very similar scene might be found in The Cyberiad, the chapter "Smoki nieprawdopodobieństwa" (Dragons of Improbability). When Klapaucjusz shoots at Trurl (disguised as a dragon) with his improbability blaster an identical chain of very improbable events materializes around them.

Even Terminus's simple brain goes mad without mutilating the robot's abilities of performing his menial work. Pirx in his anger calls Terminus "an iron madman". Terminus's psychic problem is easy to be diagnosed: he suffers from repetition-compulsion. He has to re-live his painful memories (drifting in space with the dying crew on board and listening to their agony - the banged messages) over and over again. Such a condition is probably a symptom of posttraumatic neurosis: "Now dreams occurring in traumatic neuroses have the characteristic of repeatedly bringing the patient back into the situation of his accident, a situation from which he wakes up in another fright... Fixation to the experience which started the illness has long been familiar to us in hysteria."(Freud 1967: 30-31)

The Setaur in "The Hunt" also suffers from brain damage and, similarly to Terminus, is able to function, albeit in a deviated way. He attacks everything that is moving and with his vocal apparatus he generates chains of schizzy, pseudo-jargon. In "The Inquest", in contrast, it is the people who seem to nonlinears to be schizophrenics because at one and the same time they can pursue several contradictory aims, either consciously or unconsciously. The Mask has to deal with a multiple personality problem until finally she manages to overcome conflicting memories with her master-program, logic.

\section{Epilogue}

Lem's fiction dealing with robots is thus inscribed within the American and European tradition of confronting the human being and its artificial simulacrum on psychoanalytic grounds. Stories directly influenced by "The Uncanny”, such as Angela Carter's “The Loves of Lady Purple” or J. G. Ballard's “The Smile”, show living dolls as agents inflicting madness. In a more indirect fashion, intellectually demanding SF poses difficult questions about "how it feels" to have a pre-programmed brain and to sense that somewhere is the forbidden universe of emotions and instincts. In Do Androids Dream 
ORAMUS

of Electric Sheep Philip K. Dick (by the way, Lem's favorite American SF writer) describes the scene of an android silently watching Edmund Munch's The Scream. This symbolic rendering of a robot's trauma might well have been written by Stanisław Lem.

In E. T. A. Hoffman's “The Sandman” a man talks to a doll: he confesses to her, discusses with her his life and art, believes he hears her answer, feels he is understood by her, prefers her company to other people's. Soon he starts to love the doll, and to treat her kindly or cruelly, at his whim. The doll becomes a mirror to his real moral self. Lem, though he writes from the perspective of Polish culture (which is to a far less extent influenced by Freudianism) fits this pattern of writing about human simulacra. Pirx judges people by the way they treat robots: the attitude to artificial human beings reflects man's morals and ethics. Pirx's own gentle humanity makes him respect robots' rights and feel responsible for them. Humans in their attempt to conquer the Cosmos acquire new opportunities to know themselves. Both Lem and his critics see this fact.

\author{
Dominika Oramus \\ dominika.oramus@uw.edu.pl \\ Uniwersytet Warszawski \\ Ul. Ostrobramska $84 \mathrm{~m} 129$ \\ 04-163 Warszawa \\ POLSKA / POLAND
}

\title{
Works Cited
}

Bereś, S. 2002. Tako Rzecze Lem. Kraków: Wydawnictwo Literackie.

Fiałkowski, T. 2001. Świat na krawędzi. Ze Stanisławem Lemem rozmawia Tomasz Fiałkowski. Kraków: Wydawnictwo Literackie.

Freud, S. 1967. Beyond the Pleasure Principle, James Strachey (trans.). New York, Toronto, London: Bantam Books.

Freud, S. 1973. The Uncanny. - The Standard Edition of the Complete Psychological Works of Sigmund Freud, Vol. 17, An Infantile Neurosis and Other Works, James Strachey and others (trans. and ed.), London: Hogarth and the Institute of Psychoanalysis.

Jarzębski, J. 1977. Stanisław Lem, Rationalist and Visionary. - Science Fiction Studies, $12,110-125$.

Jarzębski, J. 1989. Lem w oczach krytyki światowej. Kraków: Wydawnictwo Literackie. Jarzębski, J. 2002. Pirx i sekrety człowieczeństwa. - Opowieści o Pilocie Pirxie. Kraków: Wydawnictwo Literackie.

Jekutsch, U. 2003. Płeć maszyny. Różnice płci w opowiadaniach Stanisława Lema "Rozprawa” i "Maska”. - S. Lem, Pisarz, Mysliciel, Czlowiek. Kraków: Wydawnictwo Literackie, 276-295. 
The Uncanny Robots of Pilot Pirx: Stanistaw Lem's Tales

Krywak, P. 1994. Fantastyka Lema: Droga do "Fiaska" Kraków: Wydawnictwo Literackie.

Lem, S. 1983. More Tales of Pirx the Pilot, tr. Louis Iridarne with the assistance of Magdalena Majcherczyk and Michael Kandel, San Diego, New York and London: Harcourt Brace and Company.

Lem, S. 2002. Opowieści o Pilocie Pirxie. Kraków: Wydawnictwo Literackie.

Lem, S. 2003. Fantastyczny Lem. Kraków: Wydawnictwo Literackie.

Lem, S. 2003 Fantastyka i futurologia. Kraków: Wydawnictwo Literackie.

Parker, J. A. 1992. Gendering the Robot: Stanisław Lem's “The Mask”. - Science Fiction Studies \#57, Vol. 19, Part 2, 178-191.

Sargent, P., Zebrowski, G. 1977. How It Happened: A Chronology of the "Lem Affair." - Science Fiction Studies, 12, 129-134.

Suvin, D. 1993. Stanisław Lem. - J. Clute, P. Nicholls, eds., The Encyclopedia of Science Fiction. London: Orbit, http://www.sf-encyclopedia.com/entry/lem_stanislaw (14.05.2016). 